\title{
劣悪コンクリートの簡易診断に関する実験的研究 \\ EXPERIMENTAL STUDY ON A RAPID METHOD FOR DETECTION OF LOW QUALITY CONCRETE
}

\author{
畑中重 光*, 和 藤 浩**, 谷川 恭雄*** \\ Shigemitsu HATANAKA, Hiroshi WATO and Yasuo TANIGAWA
}

\begin{abstract}
Strength of concrete in actual structures is often judged lower than that used for structural design. It is considered to occur due to the illegal addition of water during casting procedure, insufficient compaction during construction, deterioration due to aging and severe atmosphere, etc. Such low strength concrete does not make harmful effect to a performance of structure as long as it is subjected to only service loads. Performance of structures in severe condition e.g. in large earthquakes, however, is easily predicted to be greatly affected by the strength of concrete. In the present study, a series of nondestructive tests has been carried out for finding the low strength and therefore low quality concrete in site. Testing items include scratched width by a steel nail, rebound number by a test hammer, ultrasonic velocity, etc. As a result, low quality concrete in structure may be found out rather easily by using such nondestructive testing methods. It is also pointed out that the scratching test is quite effective and easily handled considering the work in site.
\end{abstract}

Keywords: low strength concrete, low quality concrete, seismic diagnosis, scratching hardness, Young's modulus, carbonated thickness, hardness of surface, ultrasonic pulse velocity

低強度コンクリート、劣悪コンクリート、耐震診断、引っかき硬さ、静弾性倸数、中性化哚さ、表面硬度、超音波速度

1. はじめに

構造体に打設されたコンクリートは、一般に施工時には設計基準 強度を上回っており、かつ材齡が経過しても当初の強度を保持する ものと考えられている。しかし、現実には、施工不良、経年劣化な どによって構造体コンクリート強度が設計基淮強度を下回っている 可能性を否定することはできない峢えば1)-8)。常時の荷重下では、 コンクリートが低強度であることが大きな問題になることは少ない。 しかし、厳しい条件下、とくに、大地震時のコンクリート構造物の 耐力や勒性は、コンクリート強度に大きく侤存することは自明であ る。また、コンクリート構造物の非破壊試験は多種多様であり、研 究例えば 9)-12）も盛んに行われているが、とくに低強度コンクリート の発見に注目した報告はほとんど見られない。

そこで本研究では、いわゆるシャブコン等によってできた劣悪な コンクリート(ここでは、水セメント比を大きくすることで得るも のとした）を現場で比較的簡易に見極めるための一つの手段を得る ことを目的として、2シリーズの実験を行った $\left.{ }^{13)}-15\right)$ 。すなわち、 実験 I では、低強度コンクリートの力学的性質および中性化深さを 調べ、実験 II では、低強度コンクリートを評価・発見するための非 破壊試験法について検討した。なお、本研究の実験 I は材齢 7 年、 実験 II は材齡 6 年までのコンクリートについて検討した結果である。 また、本研究でとくに取り上げた釘を用いる引っかき試験は、耐震 診断のレベルでいえば、建物調查における目視調查に付随する形で
行える程度の簡易なレベルを想定している。

\section{2. 低強度コンクリートに関連する䯏查研究}

以下に、低強度レベルのコンクリートの実態を取り扱った調査結 果の中から、主なものをいくつか紹介する。

(1) 大和田ら ${ }^{1)} の$ 研究

建設年度が大正年間から昭和 56 年度に至るまでの文教施設を中 心に、226 施設についてコンクリートコアの圧縮強度試験を行い、 データを分析・検討している（図－1参照)。その結果、1964 年以

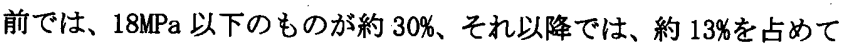
いると報告している。

(2) 大野 2) の研究

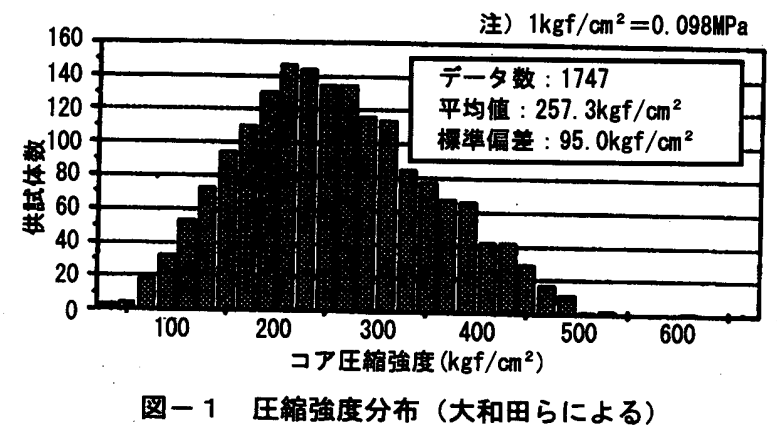

本論文は，参考文献13)-15)に修正・加笋したものである。

* 三重大学工学部建築学科 教授・ 工博

** 三重大学工学部建築学科 技術尃門職員

*** 名古屋大学大学院環境学研究科都市環境学専攻 教授・工博
Prof., Dept. of Architecture, Faculty of Eng., Mie Univ., Dr. Eng. Technical Expert, Dept. of Architecture, Faculty of Eng., Mie Univ. Prof., Division of Environmental Engineering and Architecture, Graduate School of Environmental Studies, Nagoya Univ., Dr. Eng. 
兵庫県下の解体予定の公立学校 23 棟（13 校）について、コンク リートコアの圧縮強度試験を行っている。その結果、建築基準法施 行令第 74 条による 4 週圧縮強度下限值 $12 \mathrm{MPa}$ を下回っているものが、 1963 年以前竣工のもので $25 \% 、 1964 \sim 1968$ 年竣工のもので $16 \%$ む たと報告している。また、コア供試体が設計基淮強度を下回る割合 は、1968 年以降でも、おおよそ15\%になると報告している（図ー2 参照)。

\section{(3) (財) 日本建築総合試験所の研究 ${ }^{3)}$}

兵庫県南部地震以前に竣工し、震災を受けた構造物から採取され たコンクリートコアの竣工年度別の圧縮強度分布を調べている。そ の結果、1968 年以前において 10MPa 以下、それ以後においても $15 \mathrm{MPa}$ 前後の圧縮強度のものがあることが確認できたと報告している（図 -3参照)。

\section{3. 実験方法}

\section{1 実験要因}

本実験の要因を表ー 1 に示す。ここで、表中の水中養生とは、三 重大学工学部建築学科実験室養生室内の水中㙚生 $\left(20 \pm 2^{\circ} \mathrm{C}\right)$ を、屋 外暴露とは、伊勢湾に面した 4 階建て同学科の建物の屋上（常時露 天（日陰なし）状態）で気中養生を行うことを示す。なお、試験体 は、材齢 2 日後に脱型を行い、それぞれの羡生を行った。試験体と して、各材跲および養生条件ごとに、実験 I では、 $\phi 10 \times 20 \mathrm{~cm}$ の円 柱体を、実験 II では、圧縮試験用に $\phi 10 \times 20 \mathrm{~cm}$ の円柱体を、診断用 （反発硬度、引っかき、超音波速度の各試験用）に $15 \times 15 \times 26 \mathrm{~cm}$ の角柱体を用いた。

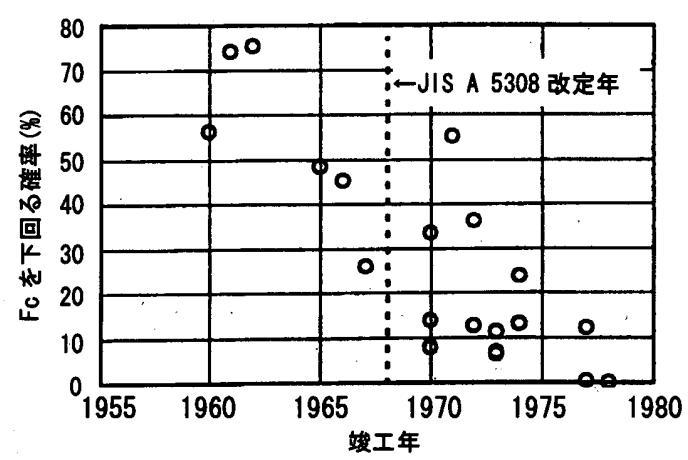

図ー2 コアの圧縮強度が設計基準強度 Fc を下回る 確率（大野による）

\begin{tabular}{|c|c|c|c|c|}
\hline & \multicolumn{2}{|r|}{ 表一 1} & \multicolumn{2}{|c|}{ 実験要因 } \\
\hline $\begin{array}{l}\text { レベル } \\
(\mathrm{MPa})\end{array}$ & 養生方法 & 村柃* & & 測定项目 \\
\hline & & 28 日 & $\begin{array}{l}\text { 实 } \\
\text { I } \\
\end{array}$ & $\begin{array}{l}\text { - 圧縮強度 } \\
\text { - 静弹性係数 } \\
\text {-中性化深さ }\end{array}$ \\
\hline $\begin{array}{c}5 \\
8 \\
12 \\
24\end{array}$ & 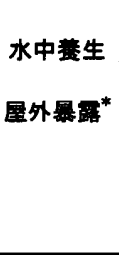 & $\begin{array}{c}91 \text { 日 } \\
1 \text { 年 } \\
6 \text { 年 } \\
(7 \text { 年) }\end{array}$ & $\begin{array}{l}\text { 荑 } \\
\text { II }\end{array}$ & 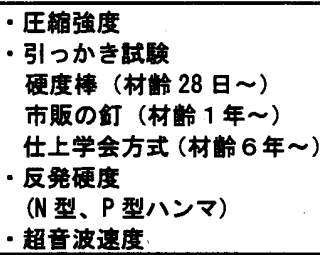 \\
\hline
\end{tabular}

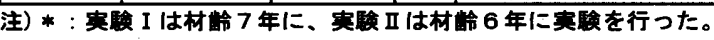

\section{2 コンクリート試験体の製作}

本実験で使用したコンクリートの使用材料の性質を表ー 2 に示 す。また、コンクリートの調合表を表ー3に示す。コンクリートの 調合は、実験 I およびII とも同一とした。目標スランプは $20 \mathrm{~cm}$ とし、 すべてワーカブルなコンクリートとした。一般には、低強度コンク リートに高性能 $\mathrm{AE}$ 減水㓮を使用することはないと言えるが、本実験 では、目標スランプを満足させる手段として、どのコンクリートに ついても一貫して高性能 $\mathrm{AE}$ 減水剤を用いることとした。コンクリー トの打込みは、実験 I では、平成 7 年 9 月中旬から下旬にかけて、 実験 II では、平成 8 年 11 月下旬から 12 月上旬にかけて、それぞれ 強度レベルの低いものから製作した。

\section{3 各実験方法の概要}

それぞれの実験の載荷、測定方法等の概要を表ー4にまとめて示 す。なお、水中養生試験体については、すべて 1 日間室内で乾燥し た後、各試験に供した。

(1)引つかき試験

コンクリート角柱体の打込み側面を、硬度棒（黄銅棒、直径 $\phi$ $1.6 \mathrm{~mm}$ 、硬度 $65 \mathrm{H}_{\mathrm{R}} \mathrm{B}$ ) および市販の比較的細い釘と太い釘（釘の形状 等を図ー4に示す）の 2 種類を先端部は加工せず、そのまま使用し て、本実験のために製作した図ー5に示す簡易な装㯰を用いて引っ かいた。おもりの重さは、硬度棒を用いる試験では $10 \mathrm{~N}$ 、釘を用い る試験では、人の力の大きさ（後述）を含むと考えられる範囲、す なわち $1 \sim 15 \mathrm{~N}$ の間で変化させた。また、この他に、人が釘で直接 引っかいた場合（ごく弱い力： $1 \mathrm{~N}$ 相当、強い力 : $15 \mathrm{~N}$ 相当）につい ても実験を行い、本装置を使用した場合のデータと比較した。また、

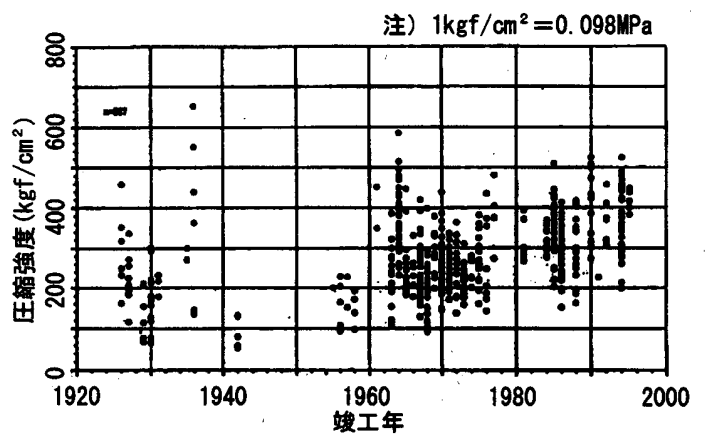

図ー3 竣工年度別コア・コンクリートの压縮強度 分布（(財)日本建築総合試験所による）

表 -2 使用材料の性筫

\begin{tabular}{|c|c|}
\hline 程類 & 物性 \\
\hline セメント & 音通ポルトランドセメント (密度 $\left.: 3.16 \mathrm{~g} / \mathrm{cm}^{3}\right)$ \\
\hline 細骨材 & 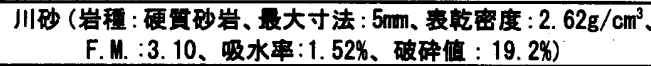 \\
\hline 粗骨材 & 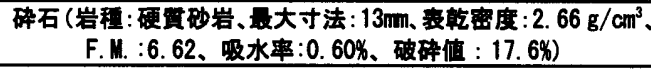 \\
\hline 混和绪 & 高性能 AE 減水凬（ポリカルボン酸塩系） \\
\hline
\end{tabular}

表ー3 コンクリートの調合表

\begin{tabular}{|c|c|c|c|c|c|c|c|c|}
\hline \multirow{2}{*}{$\begin{array}{c}\mathrm{Fc} \\
(\mathrm{MPa})\end{array}$} & \multirow{2}{*}{$\begin{array}{l}W / C \\
(\%)\end{array}$} & \multirow{2}{*}{$\begin{array}{l}\text { s/a } \\
(\%)\end{array}$} & \multicolumn{4}{|c|}{ 贯量 $\left(\mathrm{kg} / \mathrm{m}^{3}\right)$} & \multirow{2}{*}{$\begin{array}{l}\mathrm{SP} / \mathrm{C} \\
\left(\mathrm{X}^{2}\right.\end{array}$} & \multirow{2}{*}{$\begin{array}{l}\text { SL } \\
(\mathrm{cm})\end{array}$} \\
\hline & & & $W^{*}$ & c & $\mathbf{S}$ & $G$ & & \\
\hline 5 & 110 & 52 & 200 & 182 & 956 & 896 & 0.05 & \multirow{4}{*}{20} \\
\hline 8 & 90 & 50 & 190 & 211 & 921 & 935 & 0.1 & \\
\hline 12 & 70 & 48 & 180 & 257 & 879 & 967 & 0.2 & \\
\hline 24 & 55 & 46 & 170 & 309 & 834 & 994 & $\overline{0.4}$ & \\
\hline
\end{tabular}

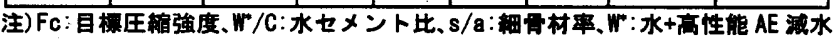

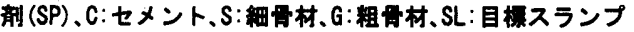


表-4 各実験方法

\begin{tabular}{|c|c|c|}
\hline \multicolumn{2}{|r|}{ 测定项目 } & 实験方法 \\
\hline \multirow{3}{*}{$\begin{array}{c}\text { 实 } \\
\text { 験 } \\
\text { I }\end{array}$} & 压艘強度 & 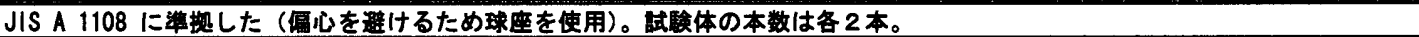 \\
\hline & 部彈性係数 & ひずみゲージを貼付して、最大荷重/3の時点で算出した。 \\
\hline & 中性化深さ & 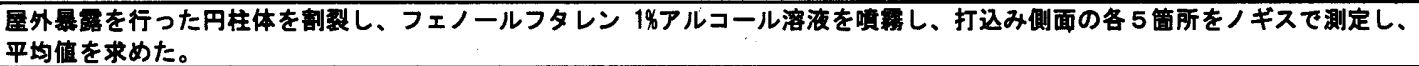 \\
\hline \multirow{4}{*}{$\begin{array}{c}\text { 実 } \\
\text { 験 } \\
\text { II }\end{array}$} & 圧雔強度 & 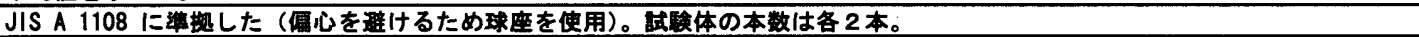 \\
\hline & $\begin{array}{l}\text { 引っかき } \\
\text { 硬さ }\end{array}$ & 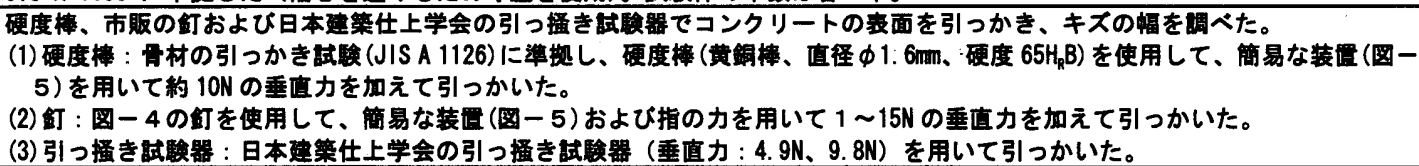 \\
\hline & 反発硬度 & 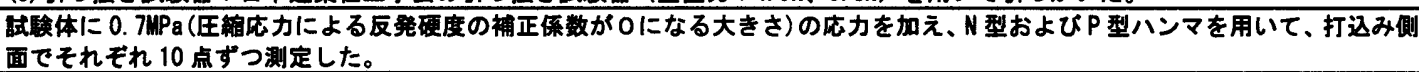 \\
\hline & 超音波速度 & 角柱体の打込み側面の相対するろ点について、直接伝逵法で测定した。 \\
\hline
\end{tabular}

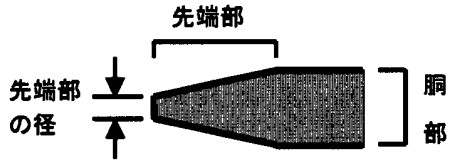

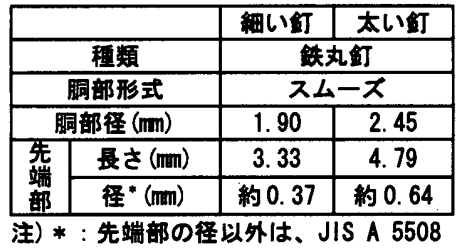
による。

図ー4 使用した釘の形状・材筫

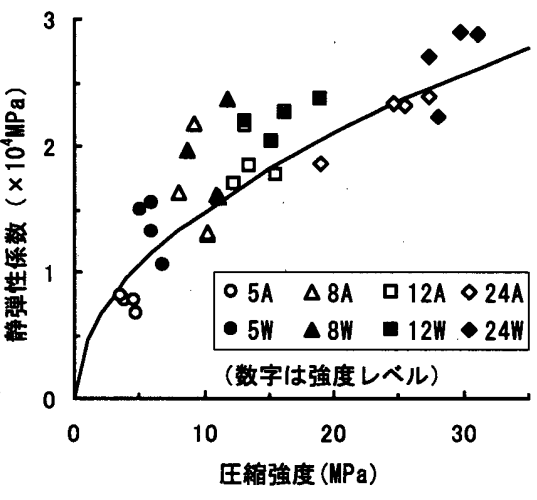

図-6 静弾性係数と圧縮強度の関係

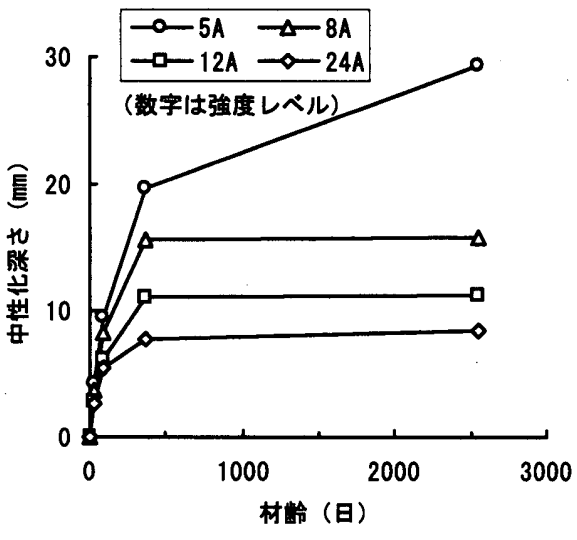

图一～中性化深さと材龄の関係

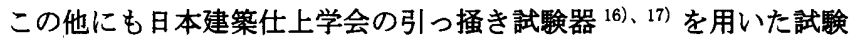
も実施した。なお、市販の釘を用いた試験については、測定 1 回ご とに釘を取り替えた。

なお、硬度棒を用いた実験は材龄 28 日より、市販の釘を用いた 実験は材齡 1 年より、日本建勧仕上学会の引つ择き試験器を用いた 実験は材齢 6 年にそれぞれ行った。

\section{(2) その他の試験}

各試験の載荷、測定方法について、表ー4にまとめて示す。

\section{4. 実験結果とその考察}

以下、図中の凡例等で使用する試験体名は、以下に示した記号に 準ずる。

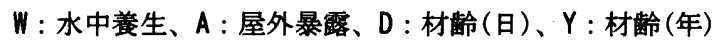

\section{1 実験 I}

\section{1.1 静弾性係数と圧縮強度の関係}

静弾性俰数と圧縮強度の関倸を図ー6に示す。図中では、材跲 28 日から 7 年のデータを同一記号で示してある。また、図中の曲線は、 日本建築学会鉄筋コンクリート (RC) 構造計算規準（1996 年版）に示 された静弾性係数の評価式において、コンクリートの密度を 2.3 $\left(\mathrm{g} / \mathrm{cm}^{3}\right)$ の一定とした場合の計算值を表したものである ${ }^{18)}$ 。 RC 規 淮式は、コンクリートの圧縮強度が 40MPa を超える場合は、実験値 を過大評価することが指摘されているが（1999 年版では、評価式の 改訂が行われた）、圧縮強度が 10MPa を下回るような低強度コンクリ 一トに対する適用性については充分な検討がなされているとはいえ ない。図によれば、普通強度のみならず低強度においても、計算值 は材齢に関保なく実験值と比較的よく一致している。また、全体的

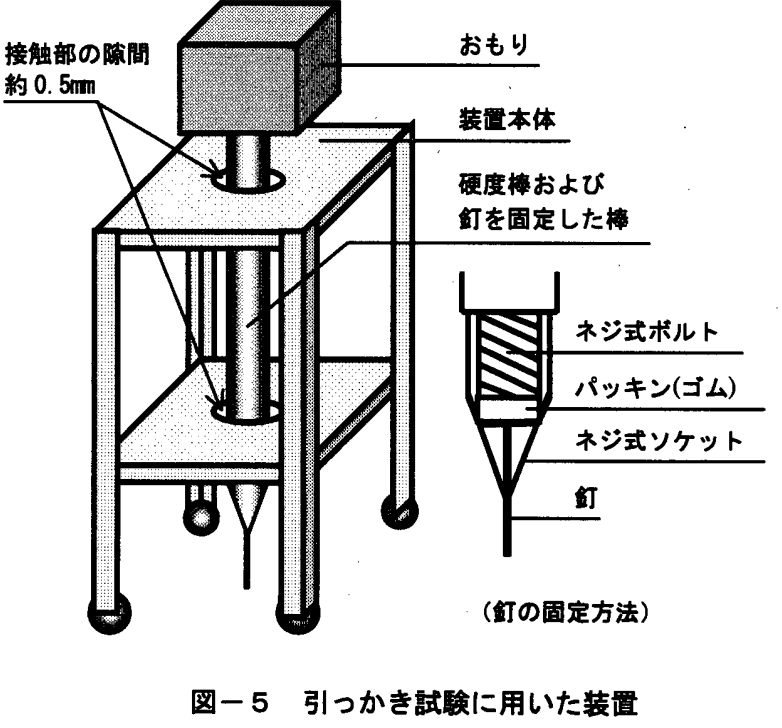

に見て水中養生試験体の方が屋外暴露試蹹体よりも同一圧縮強度時 の静弾性俰数が大きくなる傾向が見られる。

\section{1.2 中性化深さ}

屋外暴露した試験体について、中性化深さと材龄の関係を図ー 7 に示す。図によれば、材龄 28 日から材齢 7 年まで、中性化深さは強 度レベルが低くなるにつれて大きくなっている。また、材齢 28 日か ら材齢 7 年の中性化深さの進行も強度レベルが低くなるほど大きく なっている（5MPa レベルで 7.0 倍、8MPa レベルで 4.4 倍、12MPa レ ベルで 4.0 倍、24MPa レベルで 3.1 倍)。ちなみに、施工条件や環境 条件も影響するので、あくまで参考ではあるが、材齢 7 年の実測值 


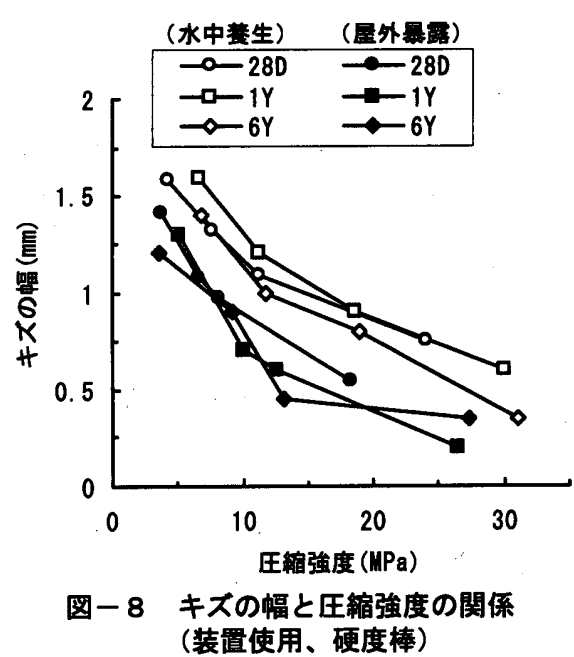

（装貫使用、硬度棒）

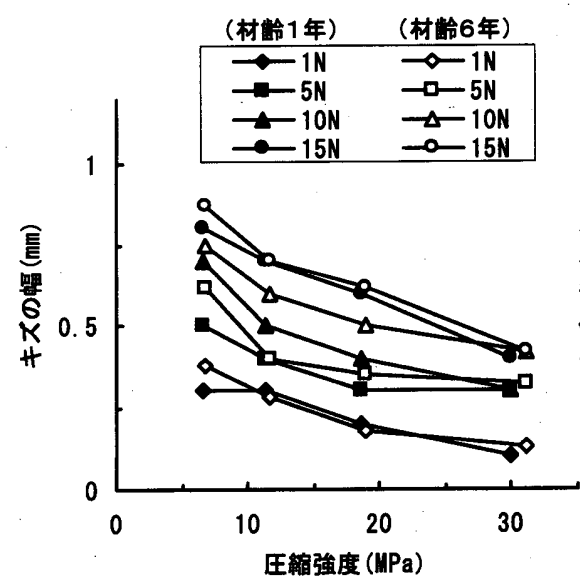

(a) 水中奉生

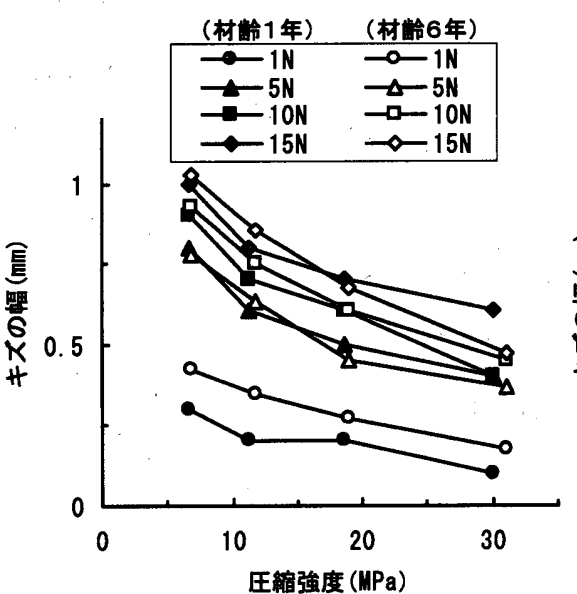

(a) 水中養生

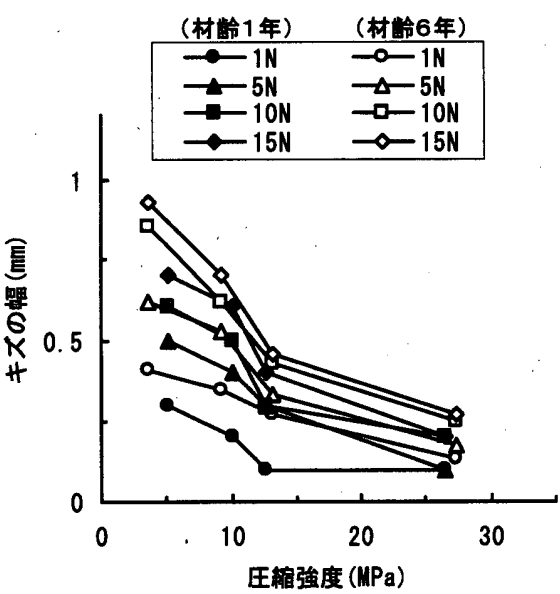

(b) 屋外暴露

图ー9 キズの幅と圧縮強度の関係（装置使用、太い钉）

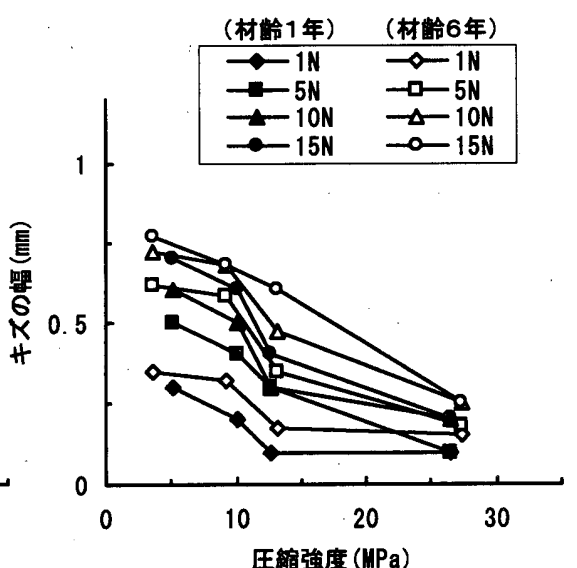

(b) 屋外暴露

图ー10キスの幅と圧縮強度の関係（装置使用、細い鲗）

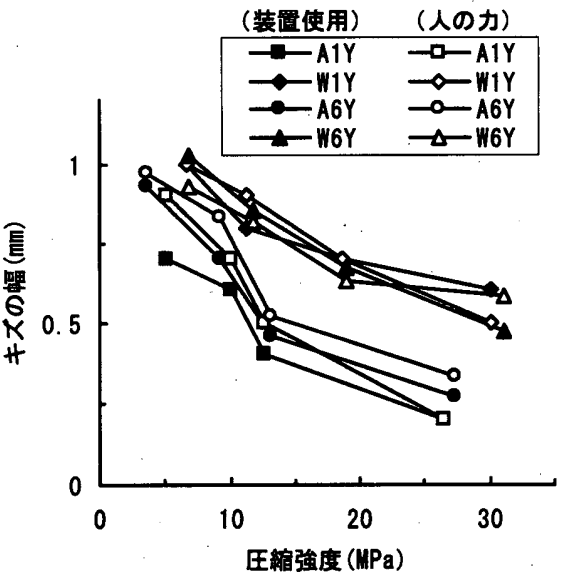

図ー11 キズの幅と圧縮強度の関係（装置と 人のカとの比較、垂直力 15N、太い煄)
(8. 4 29. 3mm) と岸谷式 ${ }^{19)}$ の計算値 $(4.6 \sim 11.7 \mathrm{~mm}) \cdot$ とを比較し たところ、前者は後者のおおよそ $1.8 \sim 2.5$ 倍であった。

\section{2 実験 II}

以下に、非破壊試験（引っかき硬さ、反発硬度、超音波速度）の 結果について述べる。

前述したように本実験は、低強度コンクリートを現場で簡易に評 価・発見することを検討したものである。なお、本報では、圧縮強 度がおおよそ $15 \mathrm{MPa}$ 以下のコンクリートを低強度コンクリートと呼 ぶこととする。

\section{2.1 引っかき試験}

\section{(1) 硬度棒（装置使用）}

コンクリート表面に対する垂直力を $10 \mathrm{~N}$ とした場合の硬度棒によ る引っかき試験の結果を図ー8に示す。図によれば、引っかきキズ の幅は、材齢にかかわらずコンクリートの強度レベルが低くなるに つれて大きくなり、同じ強度レベルでは、水中養生を行った試験体 の方が屋外暴露を行った場合より大きくなる傾向がある。また、こ れらの関保に及ぼす材齡の影響はあまり明確には見られなかった。 なお、硬度棒の場合は、測定により先端部に丸みを帯びるなどの消 耗の影響もあると考えられる。

（2）市販の煄（装置使用）
市販の釘を用い、 1 〜 $15 \mathrm{~N}$ の垂直力を加えた場合の引っかき試験 の結果を図一 9 および図ー10に示す。なお、凡例中の数值は、おも りの重さ（垂直力）を示している。これらの図によれば、引っかき キズの幅は、材齡にかかわらず、垂直力が大きいほど大きい。また、 垂直力が小さいほど、コンクリートの圧縮強度が大きいほど、グラ フの傾きが小さくなる。すなわち、垂直力が $1 \mathrm{~N}$ 以下であったり、 コンクリートの圧縮強度が $15 \mathrm{MPa}$ 以上であったりすると、圧縮強度 の変動に対するキズの幅の変化が明瞭でなくなり、強度推定上、不 都合となる。

材齡 1 年（黒マーク）と材需 6 年（白マーク）の結果を比較する と、材龄 6 年まで屋外暴露を行った試験体 (图一9 (b)、10 (b) 参照) では、強度レベル $5 \mathrm{MPa} \sim 12 \mathrm{MPa}$ においてキズの幅に増加が見られた が、その他の試験体については、あまり明確な差がないといえる。 この理由として、屋外暴露を行った試験体では、経年(材跲 1 年〜 6 年）とともに表層強度が低下したことが考えられる。また、その傾 向は、強度レベルが低くなるのに従って顕著になると考えられる。

(3) 市販の鿕（人のカ）

市販の釘を用い、垂直力をおおよそ $15 \mathrm{~N}$ として人の力で引っかい た場合と装置を用いた場合との比較を図ー11 に示す。図によれば、 若千のばらつきはあるものの、材齢にかかわらず、人の力と装置を 


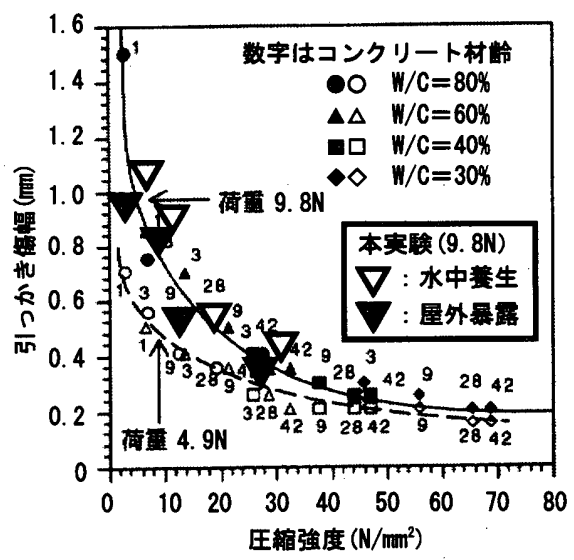

図一12 日本建築仕上学会方式によるキスの幅と 王縮強度の関係（文献 17 の図に加筆）

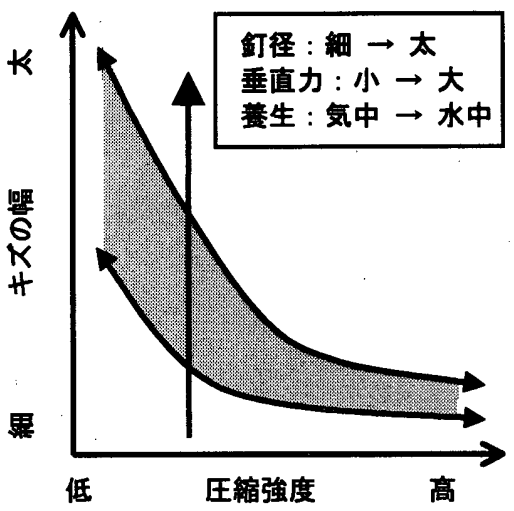

図-13 引っかき試験結果の概要

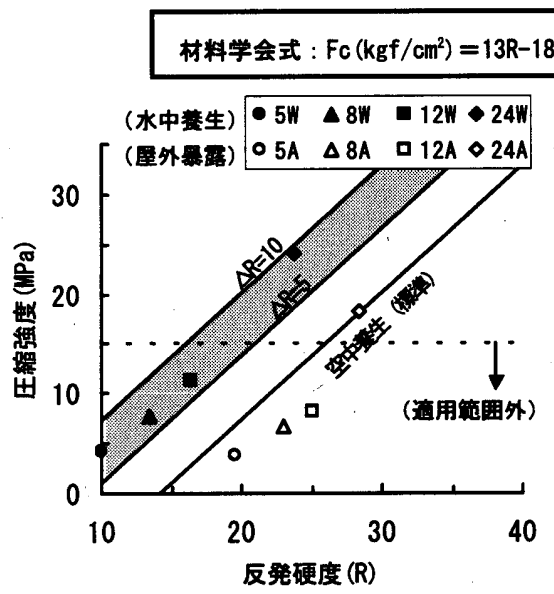

(a) 材龄 28 日

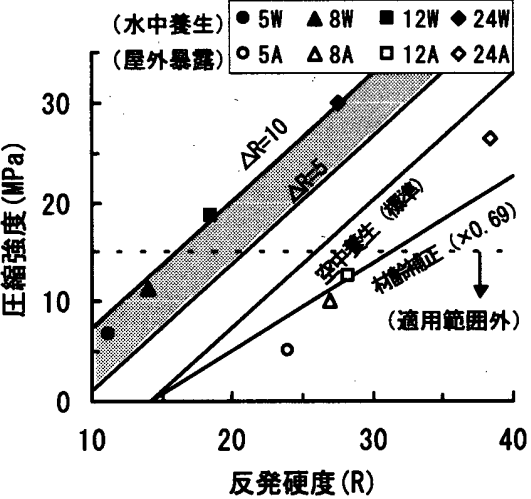

(b) 材齢 1 年

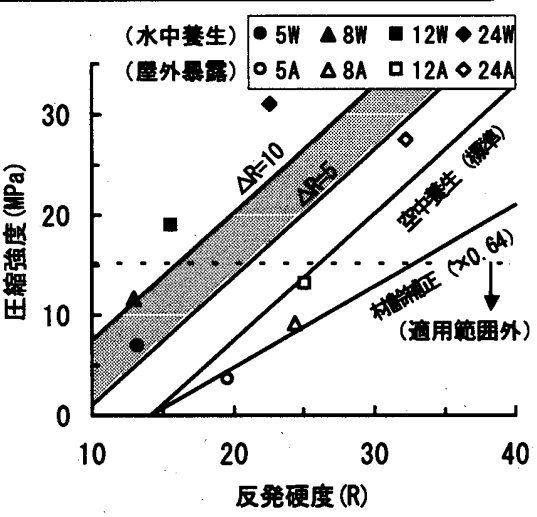

(c) 材齢 6 年

图-14 圧縮強度と反発硬度の関係（N 型ハンマ）

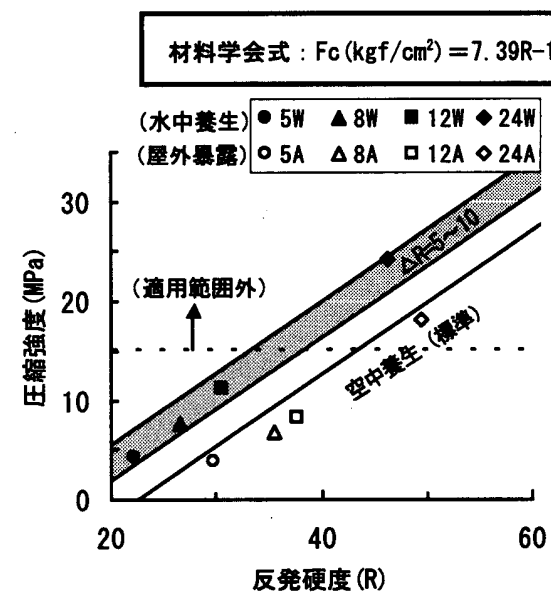

(a) 材秢 28 日

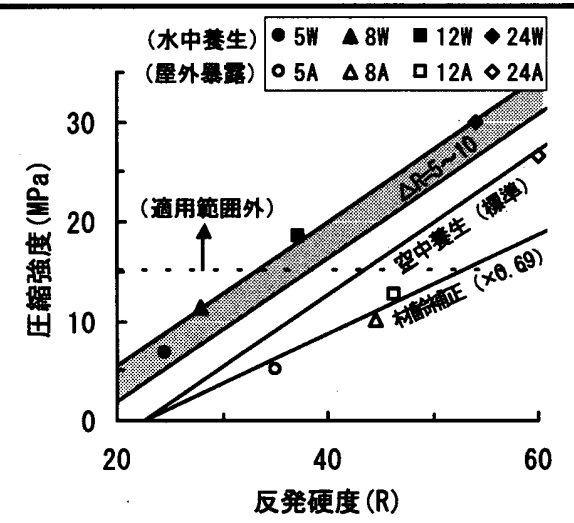

(b) 材齢 1 年

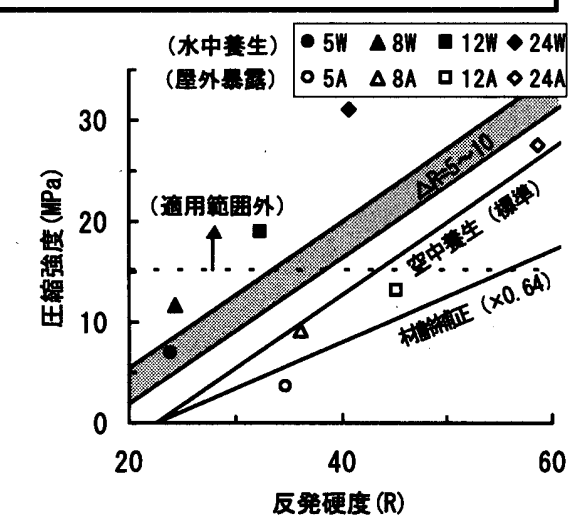

(c) 村龄 6 年

図-15 圧籍強度と反発硬度の関係 ( $\mathrm{P}$ 型ハンマ)

用いた場合の引っかきキズの幅に顕著な差は見られなかった。なお、

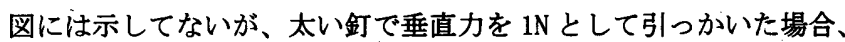

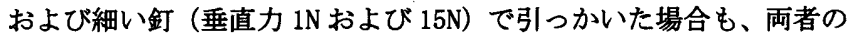
間に顕著な差は見られなかった。すなわち、材跉にかかわらず、人 の力の大きさを事前に把握しておけば、上記の装置を用いた場合と 同様に、引っかきキズの幅から低強度コンクリートの圧縮強度をお
およそ推定・評価することができそうである。

(4) 日本建築仕上学会方式（引っ掻き試験器使用）

日本建築仕上学会の引っ描き試験器を用いて測定した引っかき キズの幅と強度の関保を図ー12 に示す。図には、既往の文献 ${ }^{17)} の$ 試験結果に、材齢 6 年の本実験結果を加筆してある。図のように、 日本建築仕上学会の引っ择き試験器による引っかきキズと圧縮強度 


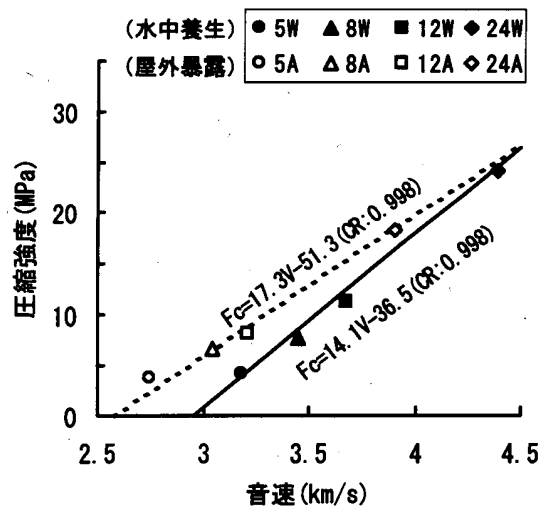

(a) 材此命 28 日

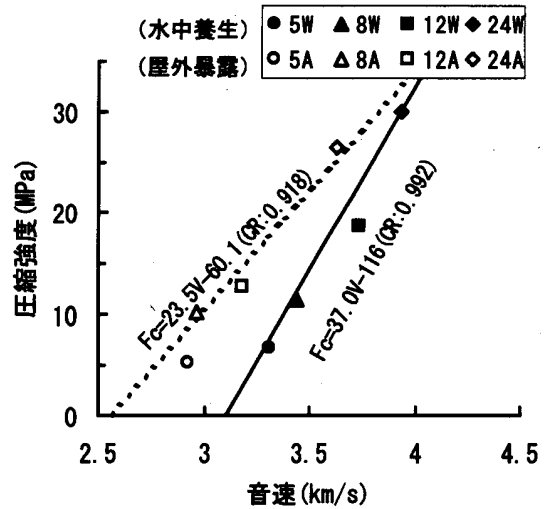

(b) 材齿 1 年

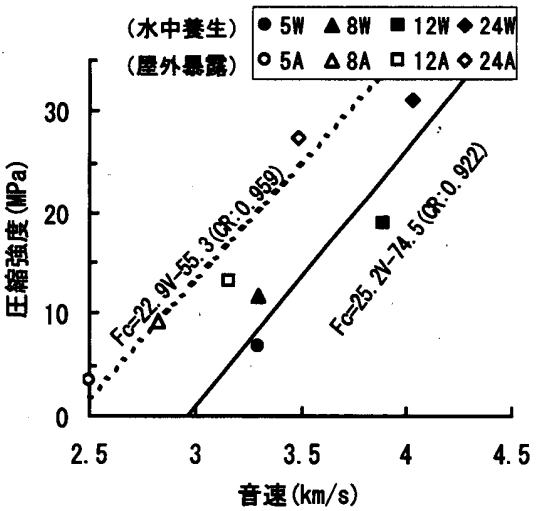

(c) 材龄 6 年

图-16 圧䈹強度と音速の関係（材齡 28 日〜材齡 6 年）

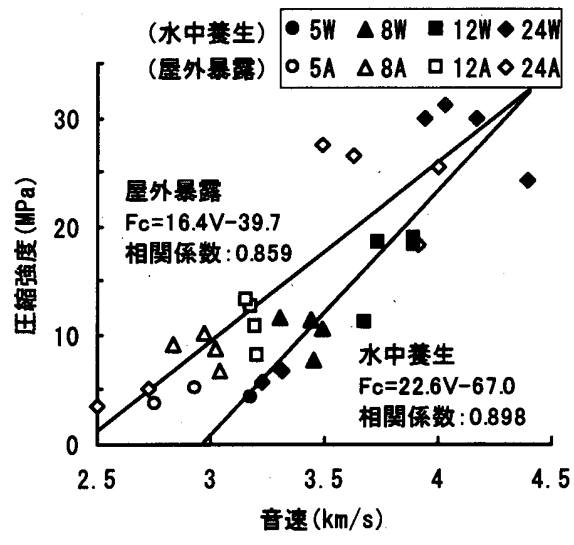

图-17 压縮強度と音速の関係（全データ）

の関係は、既往の研究結果 ${ }^{17)}$ とほぼ一致した。なお、水中養生試験 体では、屋外暴露試験体に比べ、引っかきキズ幅がわずかに大きく なる傾向が見られる。

(5) まとめ

以上の引っかき試験結果を定性的に把えるため、引っかきキズと コンクリートの圧縮強度との関係に及ほす諸要因の影響を模式的に 示せば図ー13のようになる。

15MPa 以下のような低強度コンクリートの評価・発見という観点 からすれば、キズの幅が圧縮強度の変動に対して、より敏感となる 条件のもとで試験を行うことが望ましいといえる。上記の検討結果 の範囲では、市販の釘を用いる場合、垂直力を $10 \mathrm{~N}$ 以上とし、釘は 太目のもの（ここでは、胴部径 $2.45 \mathrm{~mm}$ ）を用いるのが良い。また、 本研究と時期を同じくして検討された日本仕上学会の引っ掻き試験 も有効な装固である。いずれにせよ、引っかき試験を行う際には、 本実験で示された諸要因の影響を踏まえたうえで、キズの幅の評価 を行うことが望ましい。

\section{2 .2 反発硬度}

低強度レベルのコンクリートの強度推定に着目した研究は、これ までほとんどなされておらず、反発硬度を用いた主な推定強度式の 基礎データの測定範囲は、おおよそ $15 \mathrm{MPa}$ 以上である場合が多い。 本実験では、 $\mathrm{N}$ 型および $\mathrm{P}$ 型ハンマを用い低強度コンクリートの評

\section{表ー 5 低強度コンクリート*発見のための判断基準の例 （参考值）}

\begin{tabular}{|c|c|c|c|c|}
\hline 敦式験法 & \multirow{2}{*}{\multicolumn{2}{|c|}{$\begin{array}{l}\text { 垂直力 10N } \\
\text { 太W鲀 }^{* *}\end{array}$}} & 屋外暴露 & 水中基生 \\
\hline \multirow{2}{*}{ ひっかき硬さ } & & & $\begin{array}{l}0.4 \mathrm{~mm} \\
\text { 以上 }\end{array}$ & $\begin{array}{l}0.7 \mathrm{~mm} \\
\text { 以上 }\end{array}$ \\
\hline & \multicolumn{2}{|c|}{$\begin{array}{l}\text { 垂直力 } 15 \mathrm{~N} \\
\text { 太(红 }\end{array}$} & $\begin{array}{l}0.5 \mathrm{~mm} \\
\text { 以上 }\end{array}$ & $\begin{array}{l}0.8 \mathrm{~mm} \\
\text { 以上 }\end{array}$ \\
\hline \multirow{4}{*}{ 反発硬度 *** } & $\mathbf{N}$ & $\begin{array}{l}\text { 材粭 } \\
28 \text { 日 }\end{array}$ & $\begin{array}{l}R=25 \\
\text { 以下 }\end{array}$ & $\begin{array}{l}\mathrm{R}=20 \\
\text { 以下 }\end{array}$ \\
\hline & 型 & $\begin{array}{c}\text { 材路 } \\
1 \sim 6 \text { 年 }\end{array}$ & $\begin{array}{l}R=30 \\
\text { 以下 }\end{array}$ & $\begin{array}{l}R=15 \\
\text { 以下 }\end{array}$ \\
\hline & $\mathbf{P}$ & $\begin{array}{l}\text { 材縭 } \\
28 \text { 日 }\end{array}$ & $\begin{array}{l}R=45 \\
\text { 以下 }\end{array}$ & $\begin{array}{l}R=35 \\
\text { 以下 }\end{array}$ \\
\hline & 型 & $\begin{array}{c}\text { 材䇶 } \\
1 \sim 6 \text { 年 }\end{array}$ & $\begin{array}{l}R=50 \\
\text { 以下 }\end{array}$ & $\begin{array}{l}\mathrm{R}=30 \\
\text { 以下 }\end{array}$ \\
\hline 超音波速度 & \multicolumn{2}{|c|}{ 直接伝達法 } & $\begin{array}{l}\text { 3. } 2 \mathrm{~km} / \mathrm{s} \\
\text { 以下 }\end{array}$ & $\begin{array}{l}3.5 \mathrm{~km} / \mathrm{s} \\
\text { 以下 }\end{array}$ \\
\hline
\end{tabular}

価・発見の可能性について調べた。

$\mathrm{N}$ 型および $\mathrm{P}$ 型ハンマによる材齢 28 日、 1 年、および 6 年のコン クリートの圧縮強度と反発硬度の関俰を图ー14 および图-15に示す。 図中には、強度推定において比較的よく使用されている日本材料学 会式による計算値（式中の $\mathrm{kgf} / \mathrm{cm}^{2}$ を MPa に换算してある）と材齢

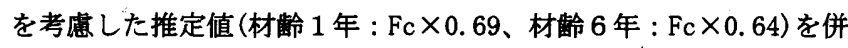
示してある。また、図ー14の N 型ハンマについては、養生方法によ る補正值（ $\triangle \mathrm{R}: 5$ ～10）を加味した推定值を併示してある。なお、 $\mathrm{P}$ 型ハンマについては、羕生方法に対する補正方法が提案されてい ないため、ここでは、N 型ハンマの補正方法を参考にして、图ー15

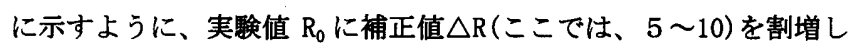
した。

これらの図によれば、材龄 1 年までの本実験結果は、養生方法に かかわらず、材料学会式に上記の補正を加えることで比較的良く推 定できそうである。しかし、材龄 6 年では、いずれのハンマを用い た場合も20MPa 以上のコンクリートは推定值が実際の圧縮強度を大 きく下回っている。一方、低強度コンクリートの圧縮強度に関して は、材料学会式をそのまま適用してもある程度の推定精度が得られ そうである。ただし、本研究の主要な目的は劣覀コンクリートの発 見にある。この観点からの検討は、4.2.4でまとめて行う。

\subsection{3 超音波速度}


圧縮強度と音速の関係を図ー16 および図ー17 に示す。図ー16に よれば、材龄にかかわらず超音波速度と圧縮強度の関保は、強い相 関性を示している。全材齢のデータに対する関係を示した図一17に よれば、相関係数は若干小さくはなるものの、超音波速度も低強度 コンクリートを評価・発見する手段として十分有用と考えられる。

\section{2.4 低強度コンクリート発見のための判断基準}

圧縮強度が $15 \mathrm{MPa}$ 程度以下の低強度コンクリートを見極める、ま たはその手掛かりを得るという観点から、以上の実験データを整理 する。養生条件など限られたデータではあるが、本実験で得られた 各種非破壊試験の結果に基づき、低強度コンクリートを発見するた めのおおよその判断基準を示せば、表一 5 のようになる。なお、反 発硬度の基準值については、既往のデータ 11)、19)も参考にした。

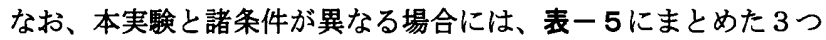
の試験法の基準值が必ずしも妥当であるとは考え難い。したがって、 3つの試験法による值のうちの一つでも基準值をおかしていれば、 低強度コンクリートの可能性があると考えるのが妥当であるう。こ こで、本研究で取り扱った試験方法を簡易なレベルから並べると以 下のようになる。

引っかき試験 $\rightarrow$ 反発硬度試験 $\rightarrow$ 超音波速度試験

劣悪コンクリートを発見するための手順としては、まず、引っか き試験を行い、その結果が基準値をおかした場合には、反発硬度や 超音波速度を測定すれば良いと考えられる。

\section{5. まとめ}

これまで必ずしも十分には調查・研究が行われてこなかった低強 度(劣悪)コンクリートについて、これを現場で見極める手段を得る ことを目的として一連の実験を行い、以下のような知見を得た。な お、本研究で取り扱った試験方法を簡易なレベルから順に並べると 以下のようになる。

引っかき試験 $\rightarrow$ 反発硬度試験 $\rightarrow$ 超音波速度試験

1)引つかきキズとコンクリートの圧縮強度との関係に及ぼす諸要因 の影響を模式的に示せば図一13のようになる。また、引っかき試 験を行う際には、本実験で示された諸要因の影響を踏まえたうえ で、キズの幅の評価を行うことが望ましい。

2)市販の釘を用いて、コンクリートの表面を人の指の力で引っかい た場合の引っかきキズの幅は、コンクリートの圧縮強度によって かなり異なり、その差異は、コンクリート強度が低くなるほど明 確になる。すなわち、15MPa 程度以下の低強度コンクリートの圧 縮強度は、材齡に関係なく、現場においても、引っかき試験によ ってある程度推定できる。

3）限られた実验データではあるが、本研究結果によれば、耐震診断 の第 1 段階で行う建物の目視調査のレベルで引っかき試験を導入 することも有用ではないかと考えられる。

4) 低強度コンクリートの評価・発見には、引っかき試験に加えて反 発硬度法や超音波速度法も適用することができる。圧縮強度がお およそ $15 \mathrm{MPa}$ 程度の低強度コンクリートを発見するための判断基 準の参考値として、表一5の値が得られた。

5)得られた判断基準 (参考値)は、養生条件など本実験の範囲内で検
討したものである。今後は、低強度コンクリートを発見するため の判断基準の汎用性をさらに高めるため、より幅広くデータを蓄 積するとともに、現場実験や実大モデル実験を行っていく必要が ある。

\section{[謝辞]}

本研究に際し、ご助力を得た岩瀬文夫氏（懒総合コンクリートサ 一ビス・代表取締役）および三島直生氏（三重大学・助手）に深謝 します。なお、本研究費の一部は、（財）日本建築センターの平成 9 年度「岸谷国際建築材料防火技術研究基金」および平成 10 年度文部 省科学研究費補助金・奨励研究 (B)によったことを付記します。

\section{[参考文献]}

1）大和田義正、木村秀雄：既存コンクリートの強度特性に関する研究、日本 建筑学会大会学術講演梗概集、C-2、pp. 791-792、1997.9.

2) 大野義照: $\mathrm{RC}$ 造の被害状況と材料施工の問題点、施工における品質管理、 日本建築学会材料施工委員会、pp. 2-20、1996.9.

3）日本建築総合試験所 : 兵庫県南部地展被災構造物から採取されたコンクリ 一ト・コア、鉄筋およびガス圧縮継手の受託強度試験の集計、pp. 25-32、 1996. 6 .

4) 木村芳幹、平澤一郎、秦邦晃、大嵦章 : 阪神地城の構造体コンクリートの 品質、コンクリート工学年次論文報告集、Vol. 19、No. 1、pp. 691-696、1997.6.

5) 今淳、最知正芳、伊藤敬一、三橋博三、田中礼治、柴田明德 : 東北地方の 既存 RC 造建物の耐展診断および耐震補强に関する調查研究 (その 4 ーコン クリート強度の分布)、日本建築学会大会学術講演梗概集、C- 2、pp. 295-296、 2000.9 .

6) 工藤仁、最知正芳、伊藤敬一、三橋博三、田中礼二、柴田明徳：東北地方 の既存 RC 造建物の耐展猃断および耐震㭪強に関する調查研究（その 5 -建 設年・建物階層別のコンクリートの強度)、日本建策学会大会学術踑演梗概 集、C- $2 、$ pp. 297-298、2000. 9.

7) 村岡康祐、瓦井一邦、寺本隆幸 : 東京都の既存 $\mathrm{RC}$ 造校舎の耐展㟝断・㭪强 に関する調査研究 (中間報告)（その 1 建物概要とコンクリート強度）、 日本建築学会大会学術講演梗概集、C-2、pp. 787-788、2001.9.

8）池口義治、瀧口克己 : 戸建て住宅の現場打ちコンクリート基蒾の経年によ 了劣化状況診断、日本建築学会構造系論文集、No. 558、pp. 39-43、2002.8. 9)柏忠二 : コンクリートの非破塄試験法、富士物産、1981.3.

10) コンクリートの非破壊試嗝法研究委員会 : コンクリートの非破壊試験法に 関するシンポジウム論文集、日本コンクリートエ学協会、1991.4.

11) コンクリートの非破壊試験法研究委員会: コンクリートの非破壊試験法に 関する各種規準（試案）、コンクリートの非破填試跲法研究委員会報告書、 日本コンクリートエ学協会、1992.3.

12）日本コンクリート工学協会 : コンクリート便臨（第 2 版）、1996.2.

13）王曉梅、和藤浩、畑中重光、谷川恭雄 : 劣悪コンクリートの简易診断に関 する実験的研究 (その1：実験方法及び実蹹結果 1)、日本建築学会大会学 術講演梗概集、A-1、pp. 623-624、1997.9.

14）和藤浩、王暁梅、畑中重光、谷川恭雄 : 劣要コンクリートの简易診断に関 する実験的研究 (その 2 : 実験結果 2 )、日本建築学会大会学術講演梗概集、 A-1、pp. 625-626、1997. 9 .

15）和藤浩、畑中重光、谷川恭雄 : 劣覀コンクリートの简易骖断に関する実験 的研究（その $3:$ 市販の釘の適用性）、日本建築学会大会学術䅜演梗概集、 A-1、pp. 521-522、1998. 9.

16)建築研究所 : 引っかき傷によるコンクリートの表面强度試酸方法(案)、既 存マンション躯体の劣化度調查・晾断技術マニュアル(案)、pp. 152-153、 2001.7.

17) 湯浅昇、笠井芳夫、松井勇 : 引っかき傷によるコンクリートの表面強度測 定方法、日本建策学会大会学術講演梗概集、A-1、pp. 677-678、1999.9.

18）日本建築学会 : 鉄筋コンクリート粠造計算規準・同解説、1998.2. 19）谷川恭雄、他：構造材料実蹹法（第 2 版）、森北出版、1996.3. 